\title{
PROFILING ENTREPRENEURIAL BEHAVIOUR BASED ON DEMOGRAPHIC VARIABLES: TOURISM-RELATED ENTREPRENEURS IN MTUBATUBA LOCAL MUNICIPALITY, SOUTH AFRICA
}

\author{
Sibusiso D. NTSHANGASE \\ University of Zululand, Department of Recreation and Tourism, Private Bag X1001, KwaDlangezwa 3886, South Africa, e-mail: sdbiyela @gmail.com
}

Ikechukwu O. EZEUDUJI*

University of Zululand, Department of Recreation and Tourism, Private Bag X1001, KwaDlangezwa 3886, South Africa, e-mail: ezeudujii@unizulu.ac.za

Citation: Ntshangase, S.D., \& Ezeuduji, I.O. (2020). PROFILING ENTREPRENEURIAL BEHAVIOUR BASED ON DEMOGRAPHIC VARIABLES: TOURISM-RELATED ENTREPRENEURS IN MTUBATUBA LOCAL MUNICIPALITY, SOUTH AFRICA. GeoJournal of Tourism and Geosites, 31(3), 944-950. https://doi.org/10.30892/gtg.31302-525

\begin{abstract}
This paper profiles entrepreneurial behaviour based on demographic variables, using Mtubatuba Local Municipality in South Africa as a case. A structured questionnaire survey was used to collect data. The study used a convenience sampling method of the non-probability sampling design to select 124 tourism-related entrepreneurs living in different regions of Mtubatuba Local Municipality, KwaZulu-Natal Province of South Africa. The results suggest that entrepreneurs' demographic variables such as 'age', 'gender', 'cultural group', 'nationality' and 'business experience' have significant influence on entrepreneurial attributes. This study is exploratory in nature and not conclusive, requiring further confirmatory studies.
\end{abstract}

Key words: entrepreneurship; tourism entrepreneurship; entrepreneurial attributes; entrepreneurial behavior; sub-Saharan Africa

$* * * * *$

\section{INTRODUCTION}

Mtubatuba Local Municipality is located within uMkhanyakude District Municipality, in the province of KwaZulu-Natal, South Africa. Mtubatuba caters for a wide spectrum of tourists and travellers, boasting the presence of iSimangaliso Wetland Park (a World Heritage Site), Mfolozi River and St Lucia Town. St Lucia is a tourism and service centre for the surrounding rural area of Mpukunyoni and a scenery belt which links the Mtubatuba Town and St Lucia Town (Mtubatuba Municipality, 2017). Its accommodation facilities (hotels, guest houses, and bed and breakfasts) compare favourably to the world standards (Nyawo and Mubangizi, 2015). Mtubatuba Local Municipality has many tourism-related businesses established by tourism entrepreneurs.

Globally, there has been much attention to entrepreneurship research, however a significant number of academic papers on this area of research have not been published in the tourism and hospitality journals (published studies include Altinay et al., 2012; Ayd emir and Ortay, 2017; Chandler and Ve Lyon, 2001; Li, 2008). The entrepreneur is usually seen as a designer or an innovator of new business ideas. Rusu et al. (2015) state that the entrepreneur is engaged or active in entrepreneurial activity with a purpose of becoming self-employed. Entrepreneurs are a significant part of the global pursuit for sustained economic development and social progress in the world (Santhi, 2017). In recent years, there has been an increasing interest in studying entrepreneurial characteristics, entrepreneurial intention s and entrepreneurial behaviour to sustain the culture of entrepreneurship. Previous research (Singh and Singh, 2016) provided valuable information regarding entrepreneurship. The aforementioned authors posit that entrepreneurship is used as an instrument to create more jobs and to eradicate poverty in the country. This means that, entrepreneurship has been considered as a key element in the process of economic growth, as it helps entrepreneurs' economic independence and improves their social status (Premand et al., 2016; Villasana et al., 2016). Actually, investigating entrepreneurial behaviour is of a continuing interest within entrepreneurship discipline. Earlier studies and researchers in the field of entrepreneurship focused much on personal characteristics that differentiate entrepreneurs from non-entrepreneurs (such as Pirnar, 2015; Santhi, 2017). This study argues that although there are differences between entrepreneurs and non-entrepreneurs, and entrepreneurs have attributes that qualify them as entrepreneurs; however, these attributes may be influenced by some demographic variables, causing entrepreneurs to behave differently. A study that explores how demographic variables may relate with different entrepreneurial attributes, as suggested in literature, is necessary. Entrepreneurs have a significant part to play in the South African economy and social progress (Pirnar, 2015). Thus, this paper explores how the entrepreneurs' demographic variables may relate with documented entrepreneurial attributes, using the case of Mtubatuba Local Municipality, KwaZulu-Natal Province in South Africa (Figure 1). There is a dearth of literature in sub-Saharan Africa regarding this study focus. This study used tourism-related entrepreneurs as respondents. This study area was chosen based on personal interest as one of the authors resides in this local municipality. Also, the researchers chose to focus on tourism-related entrepreneurs due to this study area's reliance on tourism as an economic activity and the presence of many tourism-related businesses in this part of South Africa.

\section{RELATED WORKS AND RESEARCH PROBLEM STATEMENT}

Tourism is a viable tool to enhance local economies in sub-Saharan Africa, with tourism development strategies being adopted by numerous local authorities in South Africa as a significant part of their local economic development initiatives (Abrahams, 2019; Ramukumba, 2019; Strydom et al., 2019). Tourism is one of the most rapidly growing industries and an important economic activity in most countries worldwide (Solvoll et al., 2015; World Travel and Tourism Council, 2017; Kallmuenzer and Peters, 2018). Mamabolo et al. (2017) argue that despite efforts to invest in entrepreneurship, South Africa is challenged by a low entrepreneurial activity and high unemployment rate compared to the other sub-Saharan African countries. Kallmuenzer and Peters (2018) affirm that in South Africa, chances are very slim for a new Small Medium Enterprise (SME) to survive beyond 42 months. The Global Entrepreneurship Monitor report (GEM, 2014) reveals that only about 2.3\% of South African owned SMEs have been in existence for over 3-5 years. On the 18 May 2018, Richard Downings, made a very touching statement in his speech. He said that " 8 out of 10 entrepreneurs who started businesses in South Africa failed within 
the first 18 months", especially in rural areas. This is an indication of high failure rate among start-ups. It is however, worthy to note that this situation is not only peculiar to South Africa, but is common in the rest of the world (Neneh, 2011). More recently, Iwu et al. (2016) reveal that entrepreneurial activities are very low in South Africa compared to other sub-Saharan countries.

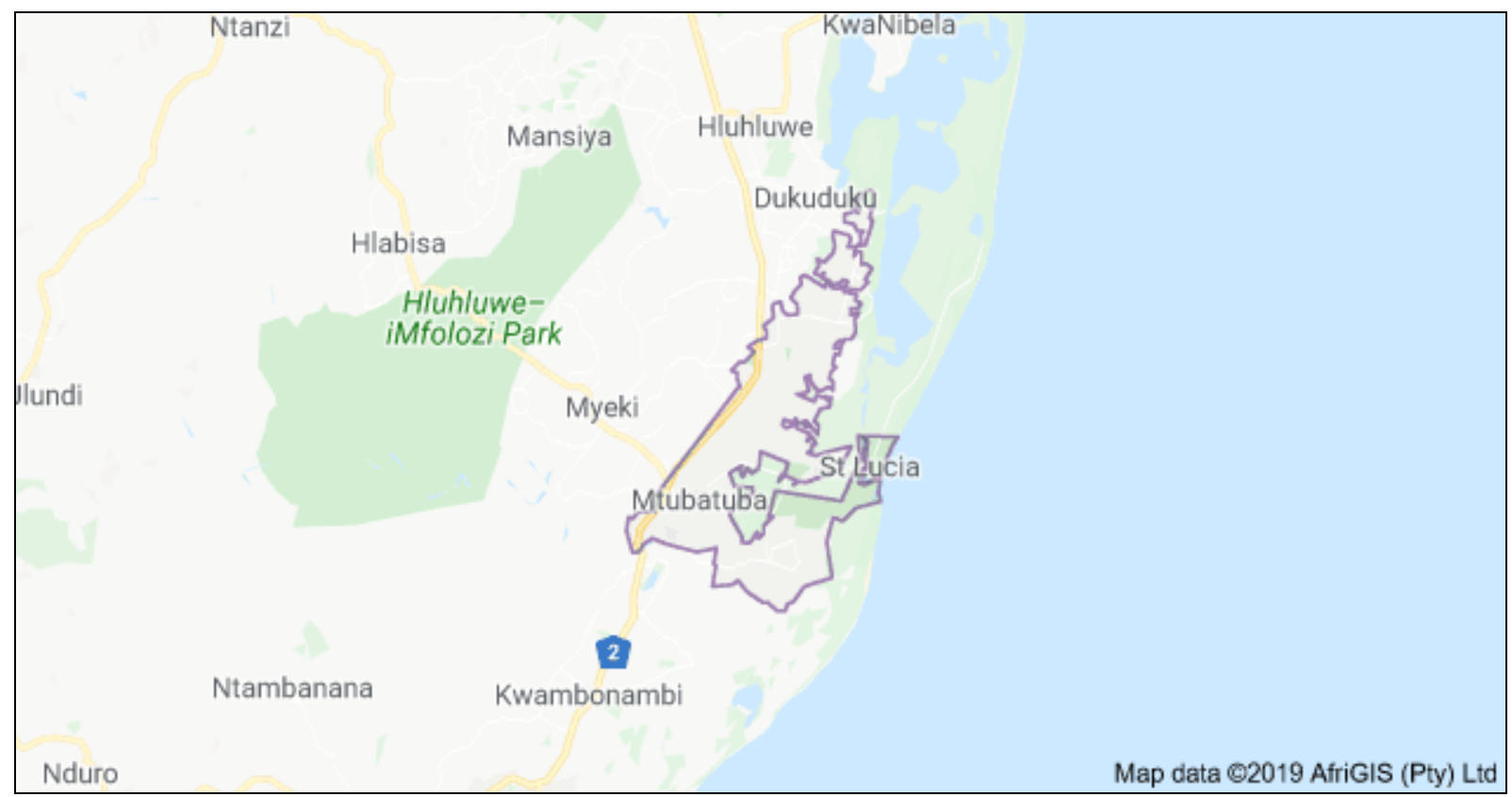

Figure 1. The map of Mtubatuba Local Municipality (Source: AfriGIS (Pty) Ltd.)

Ahmad (2015) posits that entrepreneurial ability is perceived as possession of skills necessary for the starting and nurturing to growth of a new enterprise, especially in a competitive environment. Based on the review and synthesis of relevant literature, different attributes are associated with entrepreneurs some of which the researchers found very germane to the present study. There is a large number of published studies (such as De Raffele, 2011; Pirnar, 2015; Omerzel, 2016; Premand et al., 2016; Villasana et al., 2016; Machín-Martínez and dePabslos-Heredero, 2017; Santhi, 2017) that explore various entrepreneurial attributes.

The study, based on the literature review, synthesized and adopted attribute clusters, namely: innovative thinking and networking; learning and resource acquisition; drive and enthusiasm; the use of technology; visionary and achievement motivation; level of preparedness for risk taking; and efficiency and effectiveness as the main attributes associated with entrepreneurs, also in the South African tourism industry. As stated in the introductory part of this paper, entrepreneurs are associated with certain attributes in literature, however there is a dearth of literature on how entrepreneurs differ based on demographic variables. This research explores how demographic variables (such as age, gender, ethnicity/cultural group, business experience, and nationality, etc.) may relate with documented entrepreneurial attributes, using the case of Mtubatuba Local Municipality, KwaZulu-Natal Province in South Africa.

\section{RESEARCH DESIGN AND METHODS}

Survey research is a frequently used mode of observation in the social sciences (Babbie, 2017), and the constructs to be tested in this study are better presented in quantifiable ways; hence, this study was designed as a survey. Survey entails researchers selecting a sample of respondents and administering a standardized questionnaire to each person in the sample. In most cases, tourism research need suantitative data for researchers to get the required information (Nkwanyana et al., 2016; Ezeuduji and Mbane, 2017). This research involves a large number of respondents (Goeldner and Ritchie, 2012), and a structured questionnaire was used in the sample survey. Questions in the questionnaire were set on a 5-point Likert scale: 1 - strongly agree, 2 - agree, 3 - neutral, 4 - disagree and 5 - strongly disagree. The quantitative approach allows us to generate statistical data and present them in frequencies, percentages and tables. The type of sampling used in this study was non-probability sampling as the research population is unknown (Veal, 2011). The researchers employed convenience sampling in selecting tourism-related entrepreneurs doing business in different regions of Mtubatuba Local Municipality, KwaZulu-Natal Province of South Africa.

In some of the places where the study was conducted, the researchers and the tourism-related entrepreneurs had an agreement that the questionnaires were to be dropped and later collected after completion (weekly and at times after two weeks). A total of 150 questionnaires were distributed, however the researchers used 124 questionnaires that were fully completed, for analyses. This sample size of 124 entrepreneurs was considered large enough to reach conclusions on the research purpose, especially as the number of tourism entrepreneurs in this locality is unknown and not relatively large compared to the number of those in bigger cities or towns in KwaZuluNatal, such as Durban, Pietermaritzburg, or Richards Bay. The respondents were chosen based on convenience and availability, when the researchers visited the business areas. The participants were fully informed of the purpose of the study before they partici pated in the study. Furthermore, participants were given assurance of privacy, confidentiality and anonymity with regard to the information provided. The questionnaire variables consisted of close-ended questions in a form of matrix questions, to save time for respondents, and to increase the comparability of responses (Chawla and Sondh, 2011).

Data analyses were done using IBM's SPSS version 25 software for statistical purposes. Descriptive statistics were used to generate frequency of respondent's profile (in percentages), mean scores, and standard deviation. Bivariate analyses (comparing two variables) employed Mann-Whitney U test to check for relationships between variables (Bolboacă et al., 2011). For the purpose of data analysis using Mann-Whitney U test, variables such as respondents' ethnic group and age group were re-recoded into two categories. The ethnic group variable was recoded from "Black Africans, White, Indian and Coloured" to "Black" (consisting of Black Africans, Indians, and Coloured) and "White", while the age group was recoded from "18 - 29, $30-39,40-49,50-59,60$ and above" to "Below 40 years", and "40 years and above", to allow the performance of the Mann-Whitney U test, and this was conducted at $95 \%$ confidence interval. The reliability test 
(using Cronbach's Alpha) was conducted to check for the level of internal consistencies of variables used to explain seven entrepreneurs' attribute dimensions (drive and enthusiasm, efficiency and effectiveness, innovation and networking, learning and resource acquisition, level of preparedness for risk taking, use of technology, and visionary and achievement motivation). The reliability tests conducted show internal consistency among variables used to explain all the entrepreneur success attributes. A cut-off point of 0.7 has been mostly used to denote internal consistency in social science research (Bühl and Zöfel, 2005; George and Mallery, 2003; Hair et al., 2005).

\section{RESULTS AND DISCUSSION}

The respondents that participated in the study were tourism-related entrepreneurs in Mtubatuba Local Municipality, South Africa. This study aims at profiling entrepreneurial behaviour based on demographic variables. The results in Table 1 show the profile of the respondents.

Results in Table 1 show that majority of the respondents were South Africans (75\%); and female respondents were somewhat in the majority (about 58\%). The sample consists more of the White racial group (about 53\%), suggesting that they dominate the tourism industry in this region. About $43 \%$ of the respondents were below 40 years old, and about $57 \%$ of the respondents were above 40 years old, reflecting that the sample is relatively matured. It has been argued that the younger people are more involved in entrepreneurial activities, however, most of them failed to demonstrate the level of maturity along the way, and that results in a high rate of failure of busines ses (Ramasobana and Fatoki, 2017). Most of the respondents are fairly new entrepreneurs (about 70\% of the respondents are 6 years or below in the business, while about $30 \%$ have operated their businesses for more than 6 years). The research findings by Jonker et al. (2009) confirmed that when entrepreneurs stay in business for many years, their entrepreneurial skills also increase. The results reveal that the majority of respondents are owners of accommodation businesses (about 45\%). Results in Table 2 through Table 8 show that respondents tend to agree mostly to the entrepreneur attributes statements in the questionnaire.

Table 1. Profile of the respondents $(\mathrm{N}=124)$

\begin{tabular}{|c|c|c|}
\hline Variable & Category & Frequency (\%) \\
\hline Origin & South African & 75 \\
& Non South African & 25 \\
\hline Gender & Female & 58.1 \\
& Male & 41.9 \\
\hline Ethnic group & Black (Black Africans, Indians, and Coloured) & 46.8 \\
& White & 53.2 \\
\hline Age group & Below 40 years & 42.7 \\
& 40 years or above & 57.3 \\
\hline Number of years & 6 years or below & 70.2 \\
in business & Above 6 years & 29.8 \\
\hline Type of business & Accommodation & 45.2 \\
& Food and Beverage & 14.5 \\
& Events Management & 12.9 \\
& Tour Operation & 7.3 \\
& Travel Agency & 4.0 \\
& Tour Guide & 6.5 \\
& Car rentals & 6.5 \\
& Resorts & 2.4 \\
& Consultancy & 0.7 \\
\hline
\end{tabular}

Table 2. Relationship between entrepreneur's perceptions of 'learning and acquiring resources' and entrepreneur's demographic variables

\begin{tabular}{|c|c|c|}
\hline Learning and acquiring resources - Statements & Mean $^{a}$ & $\begin{array}{c}\text { Compared with entrepreneur's } \\
\text { socio-demographic variables }^{\text {b }}\end{array}$ \\
\hline South African entrepreneurs or business owners lack the expertise to develop tourism in South Africa & 2.00 & $* *$ age group -40 years and above agree more \\
\hline Attending business courses before starting tourism business is important & 1.84 & ** age group -40 years and above agree more \\
\hline Attending any business courses after starting tourism business is important & 1.87 & * age group -40 years and above agree more \\
\hline I have the ability to learn from failure & 1.83 & N.S \\
\hline I was able to acquire resources on my own to start a tourism business & 1.87 & N.S \\
\hline I have a strong skill of acquiring financial resources to run my business & 2.04 & N.S \\
\hline I have the ability to learn new ways of doing things & 1.81 & N.S \\
\hline
\end{tabular}

Notes: ${ }^{a}$ Questionnaire was itemised along a 5-point Likert-type scale ranging from 1, Strongly agree; 2, Agree; 3, Neutral; 4, Disagree; 5, Strongly disagree

${ }^{\mathrm{b}}$ Mann-Whitney U test significance: N.S, no significant results; *, $\mathrm{p}<0.05 ;{ }^{* *}, \mathrm{p}<0.01$.

The results in Table 2 indicate that the entrepreneurs who are 40 years old and above agree more to these three entrepreneurial attributes statements: 'South African entrepreneurs or business owners lack the expertise to develop tourism in South Africa', 'attending business courses before starting tourism business is important', and 'attending any business courses after starting tourism business is important' compared with those who are younger in age. However, the entrepreneur's perceptions of the entrepreneurial attributes - 'learning and acquiring resources' show no significant relationships with these four entrepreneurial attributes statements: 'I have the ability to learn from failure', 'I was able to acquire resources on my own to start a tourism business', 'I have a strong skill of acquiring financial resources to run my business', and 'I have the ability to learn new ways of doing things' compared with the respondents' demographic variables. Interestingly, this evidence posits that entrepreneurial success has some relationship with 'the level of maturity' of the responding entrepreneurs. These results reflect those of Urban (2014), Ahmad (2015), and Premand et al. (2016) regarding positive relationships between entrepreneurial abilities and the level of maturity. In Table 3, relationship tests were conducted between entrepreneur's statements on 'innovative thinking and networking', and 'entrepreneur's demographic variables'. The results in Table 3 show that the respondents who are 40 years and above agree more than those who are below 40 years of age with this statement: 'innovation and networking are important aspects for the entrepreneur in daily business operations'. Results also show that the White ethnic group agree more than the Black ethnic group with this statement: 'I know how to create better products and services in my business'. This provides possible explanations as to why many tourism businesses owned by youths and Black ethnic group have less survival rates in South Africa. This gives room for further research. Regarding those who are below 40 years of age, the results in this study supports evidence from previous observations (such as 
Ezeuduji and Ntshangase, 2017a, b) that the tourism entrepreneurs, especially youths, are facing a number of difficulties, including lack of expertise to carry out an economic activity, lack of training, and lack of skills in the field of management and marketing.

Table 3. Relationship between entrepreneur's perceptions of 'innovative thinking and networking' and entrepreneur's demographic variables

\begin{tabular}{|c|c|c|}
\hline Innovative thinking and networking - Statements & Mean $^{a}$ & $\begin{array}{c}\text { Compared with entrepreneur's } \\
\text { socio-demographic variables }\end{array}$ \\
\hline Innovation and networking are important aspects for the entrepreneur in daily business operations & 1.46 & ** age group -40 years and above agree more \\
\hline As an entrepreneur, I depend on my own creativity to develop my business and to make a mark in the industry & 1.80 & N.S \\
\hline I believe that networking is often connected with the notion of friendship to overcome competition & 1.63 & N.S \\
\hline I know how to create better products and services in my business & 1.91 & $\begin{array}{l}\text { *White ethnic group agree more than } \\
\text { Black ethnic group }\end{array}$ \\
\hline Sometimes I depend on other business owners to be successful & 2.21 & N.S \\
\hline Networking is one of the way for entrepreneurs to know each other's product offerings & 1.88 & N.S \\
\hline $\begin{array}{l}\text { I believe my business will grow quicker if I form connections with or become a member of } \\
\text { professional bodies }\end{array}$ & 1.88 & N.S \\
\hline \multicolumn{3}{|c|}{$\begin{array}{c}\text { Reliability Statistics (innovation thinking and networking), Cronbach's Alpha }=.779, \text { N of Items }=7, \\
\text { Valid cases }=124(100 \%), \text { Excluded cases }=0(0 \%) \text {, Total }=124\end{array}$} \\
\hline
\end{tabular}

Table 4. Relationship between entrepreneur's perceptions of 'business drive and enthusiasm' and entrepreneurs' demographic variables

\begin{tabular}{|l|c|c|}
\hline \multicolumn{1}{|c|}{ Business drive and enthusiasm - Statements } & Mean $^{\text {a }}$ & Compared with entrepreneur's socio-demographic variables $^{\text {b }}$ \\
\hline $\begin{array}{l}\text { I feel motivated and energetic to make a difference in the South African } \\
\text { tourism industry }\end{array}$ & 1.60 & $\begin{array}{l}* \text { age group - 40 years and above agree more } \\
\text { *Entrepreneurs who are more than 6 years in business agree more }\end{array}$ \\
\hline How to run my business successfully is always in my mind & 1.60 & N.S \\
\hline I think I am one of the best entrepreneurs in South Africa & 2.03 & ${ }^{* F e m a l e s ~ a g r e e ~ m o r e ~ t h a n ~ m a l e s ~}$ \\
\hline I feel very attached to my business & 1.82 & N.S \\
\hline It would be difficult for me to get rid of my business & 1.73 & N.S \\
\hline $\begin{array}{l}\text { It would be easy for me to start another tourism business because of } \\
\text { experience and energy that I have }\end{array}$ & 2.06 & $*$ age group - 40 years and above agree more \\
\hline I always want to achieve greater things & 1.81 & $*$ Females agree more than males \\
\hline
\end{tabular}

Reliability Statistics (business drive and enthusiasm), Cronbach's Alpha =.710, $\mathrm{N}$ of Items = 7, Valid cases = 124 $(100 \%)$, Excluded cases = $0(0 \%)$, Total = 124

Notes: ${ }^{\mathrm{a}}$ Questionnaire was itemised along a 5-point Likert-type scale ranging from 1, Strongly agree; 2, Agree; 3, Neutral; 4, Disagree; 5, Strongly disagree

${ }^{\mathrm{b}}$ Mann-Whitney U test significance: N.S, no significant results; *, $\mathrm{p}<0.05 ; * *, \mathrm{p}<0.01$.

The results in Table 4 suggest that those who are more than 6 years in business agree more than those who are less than 6 years in business that: 'they feel motivated and energetic to make a difference in the South African tourism industry'. In accordance with the present results, previous studies have advocated that those who had no prior business experience probably inherited the business from their family members without any prior experience in managing the business. They have a bigger chance of not doing well in their businesse s (Neneh, 2011; Nene, 2015). Hence, this study agrees that training programs are very important and should be provided to low-skilled tourism entrepreneurs for the long-term survival of their businesses (Ezeuduji and Ntshangase, 2017b; Boermans and Willebrands, 2017; Santhi, 2017; Kallmuenzer and Peters, 2018). Such a lack of business skills is one of the crucial barriers to a firm's success (Pirnar, 2015; Omerzel, 2016). The most striking result to emerge from this study is that females are more energetic and confident than males. Females agree more than males to these statements: 'I think I am one of the best entrepreneurs in South Africa', and 'I always want to achieve greater things'. This is enough evidence to state that females in this study agree more to a strong business drive and enthusiasm than their male counterparts. Rasul et al. (2016) opine that these are common characteristics that describe successful entrepreneurs. Again, respondents who are 40 years and above agree more than their younger counterparts regarding business motivation.

Table 5. Relationship between entrepreneur's perceptions of 'use of technology in the business' and entrepreneur's demographic variables

\begin{tabular}{|c|c|c|}
\hline Use of technology in the business - Statements & $\operatorname{Mean}^{\mathrm{a}}$ & $\begin{array}{l}\text { Compared with entrepreneur's } \\
\text { socio-demographic variables }\end{array}$ \\
\hline The most important resource for tourism business is the Internet & 1.67 & $* *$ age group -40 years and above agree more \\
\hline Technology has a significant role in the success of the tourism entrepreneur & 1.73 & *South Africans agree more than non-South Africans \\
\hline $\begin{array}{l}\text { It helps to get additional technology education and training on an ongoing basis } \\
\text { as an entrepreneur }\end{array}$ & 1.66 & N.S \\
\hline The entrepreneur will struggle if she/he lacks modern technology & 1.84 & $\begin{array}{c}* * \text { Females agree more than males } \\
* \text { South Africans agree more than non-South Africans } \\
\end{array}$ \\
\hline $\begin{array}{l}\text { The entrepreneur's competitiveness increases by introducing and using modern } \\
\text { technologies }\end{array}$ & 1.77 & $\begin{array}{l}* * \text { Females agree more than males } \\
* \text { Entrepreneurs who are } 6 \text { years or below in business agree more }\end{array}$ \\
\hline $\begin{array}{l}\text { An entrepreneur cannot communicate effectively with his/her customers if } \\
\text { he/she cannot use technology }\end{array}$ & 1.87 & ** Females agree more than males \\
\hline Modern technology is a very important source of information for an entrepreneur & 1.75 & ** Females agree more than males \\
\hline \multicolumn{3}{|c|}{ Reliability Statistics (use of technology in the business), Cronbach's Alpha =.830, $\mathrm{N}$ of Items =7, Valid cases $=124(100 \%)$, Excluded cases $=0(0 \%)$, Total $=124$} \\
\hline
\end{tabular}

Results in Table 5 indicate that the respondents who are 40 years and above agree more strongly than those who are below 40 years of age, with this entrepreneurial attributes statement: 'the most important resource for tourism business is the Internet'. This is in line with the findings of Mamabolo et al. (2017) and Tichaawa (2017) who argue that the success of an entrepreneur greatly depends on attributes of the entrepreneur including the use of technology. Moreover, South Africans agree more than non-South Africans to these statements: 'technology has a significant role in the success of the tourism entrepreneur'; 'the entrepreneur will struggle if she/he lacks modern technology'. This concurs with previous studies that recognize technology as a key role player in determining the success of the tourism 
entrepreneur and the tourism business (African Development Bank, 2016). Female entrepreneurs tend to support the necessity of the use of technology in the business, more than their male counterparts. This shows that female entrepreneurs are more aware than their male counterparts, of the barriers and opportunities that technology can bring in the way of an entrepreneur. Most of the entrepreneurs surveyed do not have adequate computer skills and internet access in their businesses.

Table 6. Relationship between entrepreneur's perceptions of 'being visionary and having achievement motivation' and entrepreneur's demographic variables

\begin{tabular}{|c|c|c|}
\hline Being visionary and having achievement motivation - Statements & $\operatorname{Mean}^{a}$ & $\begin{array}{l}\text { Compared with entrepreneur's } \\
\text { socio-demographic variables }\end{array}$ \\
\hline I know where I will be or what I will achieve as a business owner in 5 years' time & 1.65 & $*$ Females agree more than males \\
\hline $\begin{array}{l}\text { Lack of acceptance of personal responsibility for outcomes can hinder the } \\
\text { entrepreneur's success }\end{array}$ & 1.82 & N.S \\
\hline I enjoy facing and overcoming obstacles to my ideas & 1.86 & N.S \\
\hline $\begin{array}{l}\text { Entrepreneurial achievement motivation is one of the key components for } \\
\text { entrepreneurial success }\end{array}$ & 1.68 & * Females agree more than males \\
\hline I know how to set goals and reaching these goals through my own effort & 1.87 & N.S \\
\hline I have love and passion for work in the tourism industry & 1.78 & ** White ethnic group agree more than Black ethnic group \\
\hline Hard work is very important for entrepreneurial success & 1.71 & N.S \\
\hline \multicolumn{3}{|c|}{$\begin{array}{c}\text { Reliability Statistics (being visionary and having achievement motivation), Cronbach's Alpha }=.780, \text { N of Items }=7, \text { Valid cas es }=124(100 \%), \\
\text { Excluded cases }=0(0 \%), \text { Total }=124\end{array}$} \\
\hline
\end{tabular}

In Table 6, results indicate that females agree more than males with these entrepreneurial attributes statements: 'I know whe re I will be or what I will achieve as a business owner in 5 years' time', and 'entrepreneurial achievement motivation is one of the key components for entrepreneurial success'. Previous research has established that the psychological characteristics associated with entrepreneurship is needed for entrepreneurial achievement (Chen et al., 2012). Previous studies such as Neneh (2011) and Chen et al. (2012) posit that the individuals who have a great need for achievement possess five important qualities, namely, the individual responsibility; moderate risk taker; knowledge of results of decisions; novel instrumental activities and the anticipation of the future possibilities. Entrepreneurs from the White ethnic group agree more than those from the Black ethnic group with this entrepre neurial attributes statement: 'I have love and passion for work in the tourism industry'. We can therefore infer that the entrepreneurs from the Black ethnic group have less entrepreneurial achievement motivation. Entrepreneurs who have high achievement motivation also have attitude and behaviour which support their aims (Sutanto and Eliyana, 2014). Being visionary and having achievement motivation can translate into action in order to have a significant impact on the business performance (Neneh, 2015).

Table 7. Relationship between entrepreneur's perceptions of 'preparedness for risk taking' and entrepreneur's demographic variables

\begin{tabular}{|l|c|c|}
\hline \multicolumn{1}{|c|}{ Preparedness for risk taking - Statements } & Mean $^{\mathbf{a}}$ & Compared with entrepreneur's socio-demographic variables $^{\text {b }}$ \\
\hline No matter what the odds, if I believe in something, I make it happen & 1.88 & N.S \\
\hline I always fix things that I do not like immediately & 1.64 & $*$ age group - 40 years and above agree more \\
\hline It is good to take some level of risks to succeed as a business owner & 1.75 & N.S \\
\hline I test my abilities by engaging myself in complex tasks & 1.81 & $*$ * Females agree more than males \\
\hline I am always looking for better ways to do things & 1.87 & N.S \\
\hline Wherever I have been, I have been a powerful force for creating change & 2.08 & N.S are 6 years or below in business agree more \\
\hline Taking calculated risks comes with being an entrepreneur & 1.89 & $*$ South Africans agree more than non-South Africans \\
\hline
\end{tabular}

Reliability Statistics (preparedness for risk taking), Cronbach's Alpha =.700, $\mathrm{N}$ of Items = 7, Valid cases = 124(100\%), Excluded cases = $0(0 \%)$, Total = 124

Notes: ${ }^{a}$ Questionnaire was itemised along a 5-point Likert-type scale ranging from 1, Strongly agree; 2, Agree; 3, Neutral; 4, Disagree; 5, Strongly disagree

${ }^{\mathrm{b}}$ Mann-Whitney U test significance: N.S, no significant results; * ${ }^{*} \mathrm{p}<0.05 ;{ }^{* *}, \mathrm{p}<0.01$.

The results in Table 7 show that the respondents who are 40 years and above agree more, compared with those who are below 40 years old with this entrepreneurial attributes statement: 'I always fix things that I do not like immediately'. Females and entrepreneurs who have been in business for 6 years or less agree more with this entrepreneurial attributes statement: 'I test my abilities by engaging myself in complex tasks'. South Africans agree more than non-South Africans with this entrepreneurial attributes statement: 'taking calculated risks comes with being an entrepreneur'. Two of the most important attributes for any business to grow are risk-taking and self-organisation (Omerzel, 2016; Amin and Hasbullah, 2018). More so, a real entrepreneur cannot put aside whatever problems she/he is facing; the entrepreneur must solve that problem (Bruwer and Smith, 2018). These findings strongly support those of Mohamed and Baqutayan (2016), and Boermans and Willebrands (2017). They posit that the risk attitude dimension is an important entrepreneur's attribute for success, as the risks-taking behaviour is an example of courage that must be possessed by the entrepreneurs.

In Table 8, results show that those who are 40 years and above agree more strongly than those who are below 40 years to these entrepreneurial attributes statements: 'I am good at turning resources into profitable outcomes', 'I am very concerned if I or my employees make mistakes', 'I know how to anticipate problems in advance and deal with them before they occur', and 'I am constantly seeking to improve my business operations'. Again, the White ethnic group agree more than the Black ethnic group; and entrepreneurs who are 6 years or less in business agree more with this statement: 'I am very concerned if I or my employees make mistakes'. Furthermore, females agree more than males regarding these statements: 'I know how to anticipate problems in advance and deal with them before they occur', 'I am always working hard towards delivering products or services to the customers on time', and 'I get myself or my employees regularly trained to do things better'. As far as this study is concerned, it seems that female entrepreneurs are more goal-driven than their male counterparts, especially in terms of putting more efforts in delivering better services and products to the customers. Surangi (2016) posits that the majority of the female entrepreneurs emphasized the purpose-driven nature and had more evidence of organized networking as a powerful weapon for them to succeed in the business world. They are able to create a good environment for them to operate efficiently (Omerzel, 2016). Based on the body of research on personality and entrepreneurship, entrepreneurs have to be efficient and e ffective to be able to control their behaviour and navigate business opportunities (Singh and Singh, 2016). 
Table 8. Relationship between entrepreneur's perceptions of 'being efficient and effective' and entrepreneurs' demographic variables

\begin{tabular}{|c|c|c|}
\hline Being efficient and effective - Statements & Mean $^{a}$ & $\begin{array}{c}\begin{array}{c}\text { Compared with entrepreneur's } \\
\text { socio-demographic variables }\end{array} \\
\end{array}$ \\
\hline I am good at turning resources into profitable outcomes & 1.74 & $* *$ age group -40 years and above agree more \\
\hline I am very concerned if I or my employees make mistakes & 1.63 & $\begin{array}{l}* \text { age group }-40 \text { years and above agree more } \\
* \text { White ethnic group agree more than Black ethnic group } \\
* \text { Entrepreneurs who are } 6 \text { years or below in business agree more }\end{array}$ \\
\hline I know how to anticipate problems in advance and deal with them before they occur & 1.90 & $\begin{array}{l}* * \text { age group }-40 \text { years and above agree more } \\
* \text { Females agree more than males }\end{array}$ \\
\hline I am always working hard towards delivering products or services to the customers on time & 1.75 & ** Females agree more than males \\
\hline I am constantly seeking to improve my business operations & 2.17 & $* *$ age group -40 years and above agree more \\
\hline I get myself or my employees regularly trained to do things better & 1.90 & ** Females agree more than males \\
\hline I am always making profit in my business & 1.91 & ** White ethnic group agree more than Black ethnic group \\
\hline \multicolumn{3}{|c|}{ Reliability Statistics (being efficient and effective), Cronbach's Alpha =.803, $\mathrm{N}$ of Items = 7, Valid cases = $124(100 \%)$, Excluded cases $=0(0 \%)$, Total $=124$} \\
\hline
\end{tabular}

\section{CONCLUSIONS}

This study found that the entrepreneurs' demographic variables such as 'age', 'gender', 'cultural group', 'nationality' and 'business experience' have significant influence on entrepreneurial attributes. These study results are particular to the study area (M tubatuba Local Municipality, South Africa) at the time the study was conducted, and cannot be generalized across regions and nations. This study has limitation as it made use of convenience sampling (a non-probability sampling method). It therefore implies that one has to be careful in interpreting or implementing the results, as the results can be statistically argued to not be representative of the study population (Mtubatuba Local Municipality). This study however is significant as it contributes to the body of knowledge regarding how demographic variables may influence entrepreneurial attributes.

The older entrepreneurs studied (40 years of age and above), place more importance than the younger ones on 'learning and acquiring resources', 'innovative thinking and networking', 'business drive and enthusiasm', and 'being efficient and effective'. Female entrepreneurs demonstrated stronger possession of entrepreneurial attributes of 'business drive and enthusiasm', 'use of tech nology in the business', 'being visionary and having achievement motivation', and 'being efficient and effective' than their male counterparts. Entrepreneurs belonging to the White ethnic group demonstrated stronger possession of entrepreneurial attributes of 'innovati ve thinking and networking', 'being visionary and having achievement motivation', and 'being efficient and effective' than those in the Black ethnic group. South African entrepreneurs place more importance than non-South African entrepreneurs regarding 'use of technology in the business', and 'preparedness for risk taking'. Finally, entrepreneurs who have 6 years or longer business experience demonstrated somewhat stronger possession of entrepreneurial attributes of 'business drive and enthusiasm', 'use of technology in the business', 'preparedness for risk taking', and 'being efficient and effective'.

Further research is needed in other regions of the world to validate the findings of this study (as this research is explorat ory in nature) and shed more light into the probable causal factors regarding these demographic differences in entrepreneurial behaviour. Cultural differences across the world regions can also be established using multivariate analyses of data collected from larger sample sizes, as this study is only descriptive employing bivariate analysis.

\section{REFERENCES}

Abrahams, D. (2019). Transformation of the tourism sector in South Africa: A possible growth stimulant? GeoJournal of Tourism and Geosites, 26(3), 821-830. Ahmad, S.Z. (2015). Entrepreneurship education in tourism and hospitality programs. Journal of Hospitality \& Tourism Education, 27(2), 20-29.

Altinay, L., Madanoğlu, M., Daniele, R., \& Ve Lashley, C. (2012). The influence of family tradition and psychological traits on entrepreneurial intention. International Journal of Hospitality Management, 31, 489-499.

Amin, S., \& Hasbullah, H. (2018). Linking personal attributes, technical skill and managerial competence towards entrepreneurial orientation and the success of traditional home culinary industry. Jurnal Perspektif Pembiayaan dan Pembangunan Daerah, 5(3), 157-166.

Aydemir, B., \& Ortay, S. (2017). Otelcilik ve turizm yönetimi dergilerinde yayınlanan girişimcilik araştırmalarının gelişimi (2007-2015) / The development of entrepreneurship research published in the hospitality and tourism management Journals (2007-2015). Journal of Entrepreneurship \& Development / Girisimcilik ve Kalkinma Dergisi, 12(2), 91-97.

Babbie, E. (2017). The basics of social research. Boston (MA), Cengage learning.

Boermans, M., \& Willebrands, D. (2017). Entrepreneurship, risk perception and firm performance. The Tjalling C. Koopmans Institute is the research institute, Discussion Paper Series 17-04. Retrieved from http:// www.uu.nl/rebo/economie/discussionpapers, date: on 06. 21.2018

Bolboacă, S.D., Jäntschi, L., Sestraş, A.F., Sestraş, R.E., \& Pamfil, D.C. (2011). Pearson-Fisher Chi-Square statistic revisited. Information, 2 (3), 528-545.

Bruwer, J.P., \& Smith, J. (2018). The role of basic business skills development and their influence on South African small, medium and micro enterprise sustainability. Journal of Economics and Behavioral Studies, 10(2), 48-62.

Bühl, A., \& Zöfel, P. (2005). SPSS 12. Einführung in die moderne Datenanalyse unter Windows. München, Addison-Wesley.

Chandler, G.N., \& Ve Lyon, D.W. (2001). Issues of research design and construct measurement in entrepreneurship research: The past decade. Entrepreneurship Theory and Practice, 26(4), 101-113.

Chawla, D., \& Sondhi, N. (2011). Research methodology: Concepts and cases. London/ New Delhi. Vikas Publishing house PVT LTD.

Chen, S., Su, X., \& Wu, S. (2012). Need for achievement, education, and entrepreneurial risk-taking behavior. Social behavior and personality, $40(8), 1311-1318$.

De Raffele, F. (2011). The 10 attributes of successful entrepreneurs. Hudson Valley Business Journal, 22(16), 6-7.

Ezeuduji, I.O., \& Mbane, T.L. (2017). Business administration and business economics. Acta Universitatis Danubius Oeconomica, 13 (2), 5-16.

Ezeuduji, I.O., \& Ntshangase, S.D. (2017a). Entrepreneurial intention: South African youth's willingness to start tourism businesses. Acta Universitatis Danubius Oeconomica, 13(5), 48-58.

Ezeuduji, I.O., \& Ntshangase, S.D. (2017b). Entrepreneurial inclination: South African youth's mental attitude towards starting tourism business. Journal of Economics and Behavioral Studies, 9(4), 144-152.

George, D. \& Mallery, P. (2003). SPSS for Windows step by step: A simple guide and reference. 11.0 update (4th Ed.). Boston, MA, Allyn \& Bacon.

Goeldner, C.R., \& Ritchie, J.R.B. (2012). Tourism: principles, practices, philosophies. New Jersey, John Wiley \& Sons.

Hair, J.H.,Jr., Black, W.C., Babin, B.J., \& Tatham, R.L. (2005). Multivariate data analysis. Upper Saddle River, NJ, Prentice-Hall.

Iwu, C.G., Ezeuduji, I.O., Eresia-Eke, C., \& Tengeh, R. (2016). The entrepreneurial intention of university students: The case of a University of Technology in South Africa. Acta Universitatis Danubius Oeconomica, 12(1), 164-181. 
Jonker, E., Saayman, M., \& De Klerk, S. (2009). The role and attributes of entrepreneurs at South Africa's largest arts festival. Revista de Turismoy Patrimonio Cultural, 7(3), 381-392.

Kallmuenzer, A., \& Peters, M. (2018). Entrepreneurial behaviour, firm size and financial performance: The case of rural tourism family firms. Tourism Recreation Research, 43(1), 2-14.

Li, L. (2008). A review of entrepreneurship research published in the hospitality and tourism management journals. Tourism Management, 29 , 1013-1022.

Machín-Martínez, M., \& de-Pablos-Heredero, C. (2017). Innovating and entrepreneurial initiatives: Some cases of success. Issues in Informing Science and Information Technology Education, 14, 139-161.

Mamabolo, M.A., Kerrin, M., \& Kele, T. (2017). Entrepreneurship management skills requirements in an emerging economy: A South African outlook. Southern African Journal of Entrepreneurship and Small Business Management, 9(1), 1-10.

Mohamed, S., \& Baqutayan, S. (2016). The entrepreneurial characteristics of successful entrepreneurs: Effective psychological model from Holy Quran and Islamic History. Specialty Journal of Accounting and Economics, 2(1), 50-59.

Neneh, B.N. (2011). The impact of entrepreneurial characteristics and business practices on the long-term survival of Small and Medium Enterprises (SMEs). Unpublished master's thesis, University of the Free State, Bloemfontein.

Neneh, B.N. (2015). Entrepreneurial self-efficacy (ESE) and small business performance: The mediating effect of entrepreneurial mindset and openness to experience. Problems and Perspectives in management, 13(4-1), 271-280.

Nkwanyana, M.S., Ezeuduji, I.O., \& Nzama, A.T. (2016). Cultural heritage tourism in South Africa: Perceived a panacea for rural development? Acta Universitatis Danubius Oeconmica, 12(6), 160-167.

Nyawo, J., \& Mubangizi, B.C. (2015). Art and craft in local economic development: Tourism possibilities in Mtubatuba Local Municipality. African Journal of Hospitality, Tourism and Leisure, 4(2), 1-15.

Omerzel, D.G. (2016). The impact of entrepreneurial characteristics and organisational culture on innovativeness in tourism firms. Managing Global Transitions: International Research Journal, 14(1), 93-110.

Pirnar, I. (2015). The specific characteristics of entrepreneurship process in tourism industry. Selçuk Ün. Sos. Bil. Ens. Der, 34(4), 75-86.

Premand, P., Brodmann, S., Almeida, R., Grun, R., \& Barouni, M. (2016). Entrepreneurship education and entry into self-employment among university graduates. World Development, 7(7), 311-327.

Ramasobana, M. \& Fatoki, O. (2017). Business attributes and marketing communication strategies of SMEs in South Africa. Journal of Economics and Behavioral Studies, 9(6), 90-97.

Ramukumba, T. (2019). Community views on the role of tourism in local development: A South African study. GeoJournal of Tourism and Geosites, 25 (2), 638-647.

Rasul, F., Fatima, U., \& Sohail, S. (2016). Religion tourism and entrepreneurial development (a case study hazrat data ganj bakhsh shrine). A Research Journal of South Asian Studies, 31(1), 275-289.

Rusu, S., Isac, F., \& Cureteanu, R. (2015). Worldwide tourism entrepreneurship, A global perspective. Agricultural Management / Lucrari Stiintifice Seria I, Management Agricol, 17(4), 64-68.

Santhi, A.B. (2017). Women entrepreneurship: problem and prospects: A study of chittoor district. International Journal of Research in Commerce \& Management, 8(6), 6-11.

Singh, P.S. \& Singh, H.R. (2016). Entrepreneurial inclination: A critical review. Indian Journal of Research, 5(2), 69-73.

Solvoll, S., Alsos, G.A., \& Bulanova, O. (2015). Tourism entrepreneurship - review and future directions. Scandinavian Journal of Hospitality and Tourism, $15(1), 120-137$

Strydom, A.J., Mangope, D., \& Henama, U.S. (2019). Making community-based tourism sustainable: Evidence from the Free State Province, South Africa. GeoJournal of Tourism and Geosites, 24(1), 7-18.

Surangi, H.A.K.N.S. (2016). The role of female entrepreneurial networks and small business development: a pilot study based on Sri Lankan migrant entrepreneurs of tourism industry in London. International Journal of Business and Economic Development, 4(1), 56-70.

Sutanto, E.M., \& Eliyana, A. (2014). The study of entrepreneurial characteristics with achievement motivation and attitude as the antecedent variables. International Refereed Research Journal, 4(11), 125-136.

Tichaawa, T.M. (2017). Business tourism in Africa: the case of Cameroon. Tourism Review International, 21(2), 181-192.

Urban, B. (2014). The importance of attributes in entrepreneurial opportunity evaluations: An emerging market study. Managerial and Decision Economics, $3(5), 523-539$.

Veal, A.J. (2011). Research methods for leisure and tourism: A practical guide (4th Ed.). Harlow, UK, Financial Times Prentice Hall.

Villasana, M., Alcaraz-Rodríguez, R., \& Alvarez, M.M. (2016). Examining entrepreneurial attributes of Latin American female university students. Gender \& Education, 28(1),148-166.

***African Development Bank (2016). Sustainable tourism through innovation, entrepreneurship, and technology. Africa Tourism Monitor, 4(1),1-64.

*** GEM (2014). Global Entrepreneurship monitor. 2014 Global report. Retrieved from http://www.baruch.cuny.edu/news/documents/GEM2014.pdf, date: 08. 14. 2018.

***Mtubatuba Municipality (2017). Local economic development. Retrieved from http://www.kzntopbusiness.co.za/site/mtubatuba-municipality, date: 13.02.2018.

$* * *$ World Travel \& Tourism Council (2017). Travel \& tourism economic impact South Africa. WTTC (World Travel and Tourism Council), 1998. South Africa's travel and tourism economic driver for the 21 st century. London, WTTC. 